\title{
STUDI IMPLEMENTASI VOIP BERBASIS SIP JARINGAN KAMPUS UNIVERSITAS SAM RATULANGI
}

\author{
Meicsy Najoan \\ Program Studi Teknik Elektro, Fakultas Teknik, Universitas Sam Ratulangi Manado, Jl. Kampus Unsrat \\ Bahu, Malalayang, Manado, Sulawesi Utara, 95115, Indonesia \\ E-mail: meksy_najoan@yahoo.com
}

\begin{abstract}
Abstrak
Voice Over Internet Protocol (VoIP) adalah salah satu contoh perkembangan teknologi komunikasi dan informasi saat ini. Teknologi VoIP sangat menguntungkan karena menggunakan jaringan berbasis IP yang sudah memiliki jaringan kuat di dunia sehingga biaya untuk melakukan panggilan jauh lebih efisien daripada menggunakan telepon analog. Dengan memanfaatkan jaringan komputer yang sudah ada memungkinkan teknologi VoIP dapat diimplementasikan di Universitas Sam Ratulangi Namun yang menjadi masalah dalam penggunaan teknologi ini adalah banyaknya persepsi yang menyatakan bahwa kualitas suara pada percakapan VoIP masih tergolong buruk. Hal ini banyak disebabkan oleh penggunaan codec yang tidak sesuai dengan kapasitas jaringan dan masalah pada jaringan IP yang digunakan yang pada akhirnya menyebabkan terjadinya delay, jitter, dan packet loss .Oleh karena itu perlu dilakukan analisis sebelum teknologi ini dijalankan. Dengan alasan di atas penulis melakukan analisis dari segi teknis mulai dari monitoring keadaan jaringan, kualitas sambungan/suara yang dipengaruhi oleh beberapa parameter penting yang mempengaruhi QoS (Quality of Service), serta performansi codec yang digunakan. Adapun codec yang diuji adalah codec GSM, iLBC, G.729, dan G.711. Dari hasil penelitian secara umum, parameter-parameter yang mempengaruhi kualitas sambungan/suara seperti delay, jitter dan packet loss tergolong baik untuk dijalankan di jaringan kampus Unsrat. Adapun alternatif jenis codec yang baik digunakan yaitu G.711 karena memiliki performansi yang lebih dibanding jenis codec yang lain. Dari hasil penelitian ini mengindikasikan Universitas Sam Ratulangi layak untuk mengimplementasikan teknologi ini.
\end{abstract}

Kata Kunci: VoIP, Codec, QoS

\section{Pendahuluan}

Internet merupakan suatu sistem interkoneksi yang menghubungkan jaringan komputer di seluruh dunia yang dapat mentransmisikan paket-paket data menggunakan protokol standar, yaitu TCP/IP. Paket-paket data ini dapat merupakan paket-paket yang bersifat non real-time, seperti email, file sharing, dan dapat juga bersifat real-time, seperti VoIP atau video streaming. Perkembangan teknologi Internet yang sedemikian pesat ini telah memicu munculnya berbagai teknologi baru yang diharapkan mampu memenuhi kebutuhan manusia akan komunikasi yang lebih sempurna dari hari ke hari. Salah satu teknologi yang diharapkan mampu memenuhi kebutuhan tersebut adalah teknologi Multimedia. Multimedia didefinisikan sebagai komunikasi yang menggunakan kombinasi antara berbagai media dan mungkin melibatkan Personal Computer (PC) didalamnya. Multimedia sendiri merepresentasikan data dalam bentuk teks, voice, audio, video, musik, gambar, animasi dll.

Voice yang merupakan bagian dari teknologi multimedia dalam perjalanannya mengalami banyak perkembangan diantaranya kita kenal dengan teknologi Voice Over Internet Protocol (VoIP). Secara umum VoIP didefinisikan sebagai suatu sistem yang menggunakan jaringan Internet untuk mengirimkan data paket suara dari satu tempat ke tempat lain menggunakan perantara protokol IP (tharom, purbo: 2001). VoIP sendiri ialah teknologi yang memungkinkan komunikasi suara menggunakan jaringan berbasis IP (Internet Protocol) untuk dijalankan diatas infrastruktur jaringan paket network. Teknologi ini bekerja dengan jalan merubah suara menjadi format data digital tertentu yang dapat dikirimkan melalui jaringan IP. Layanan telepon internet (VoIP) 
merupakan layanan yang bersifat real-time, oleh karena itu beberapa parameter yang mempengaruhi kualitas layanan seperti waktu tunda (delay), variasi waktu tunda (jitter), tingkat paket hilang (packet loss), merupakan faktor utama yang mempengaruhi kualitas layanan telepon internet ini.

Hampir di setiap perusahaan maupun institusi terdapat jaringan komputer untuk memperlancar arus informasi, begitu juga pada kampus Universitas Sam Ratulangi. Teknologi informasi telah cukup lama di manfaatkan di kampus ini untuk menunjang kegiatan belajar mengajar. Dalam pelaksanaannya, kampus Universitas Sam Ratulangi telah memiliki infrastruktur jaringan komputer dan internet yang terhubung keseluruh gedung. Dengan adanya jaringan komputer yang telah terintegrasi saat ini di lingkungan kampus Universitas Sam Ratulangi, dan untuk menunjang program kampus itu sendiri yaitu membangun komunikasi telepon internet (VoIP Unsrat) 2010, maka di pandang perlu melakukan studi atau kajian sebelum program penerapan voip ini di jalankan.

Tujuan penelitian ini yaitu untuk meneliti hubungan antara parameter jaringan seperti waktu tunda, variasi waktu tunda, dan tingkat paket hilang, terhadap kualitas panggilan VoIP dari beberapa kompresi suara yang umumnya digunakan, dengan berdasarkan kondisi jaringan yang ada, sehingga diharapkan bermanfaat dalam memberikan gambaran dan pertimbangan layak tidaknya teknologi komunikasi telepon digital untuk di implementasikan di jaringan kampus Universitas Sam Ratulangi kedepan

\section{Arsitektur VoIP}

Arsitektur VoIP punya beberapa kemiripan dengan jaringan konvensional Public Swich Telephone Network (PSTN). Jika dibandingkan sistem kerjanya, PSTN melewatkan data melalui media jaringan kabel. Jaringan komunikasi data ini mengirimkan data suara berbasis circuit switch. Telepon langsung terhubung dengan PABX (Private Automated Branch Exchange). Dalam PABX ini ada daftar nomor-nomor telepon yang disusun secara beertingkat sesuai dengan daerah cakupannya. Jika dari pesawat telepon tersebut mau menghubungi rekan yang lain maka tuts pesawat telepon yang ditekan akan menginformasikan lokasi yang dituju melalui nada-nada DTMF, kemudian jaringan akan secara otomatis menghubungkan kedua titik tersebut. Dari PABX terhubung ke Central Office (CO), yang menghubungkan bebrapa PBX. Antara CO pun saling terhubung sehingga setiap nomor telepon bisa saling berkomunikasi. Secara umum, arsitektur jaringan VoIP memiliki kemiripan dengan jaringan PSTN. Jaringan VoIP dilewatkan pada jaaringan berbasis packet switched. Yang berperan sebagai PABX dan $\mathrm{CO}$ disini adalah router. Perkembangan teknologi VoIP saat ini mendorong ke arah konvergensi dengan teknologi komunikasi lainnya. Standarisasi protokkol komunikasi pada teknologi VoIP telah memungkinkan komunikasi terintegrasi dengan jaringan komunikasi lainnya seperti PSTN.

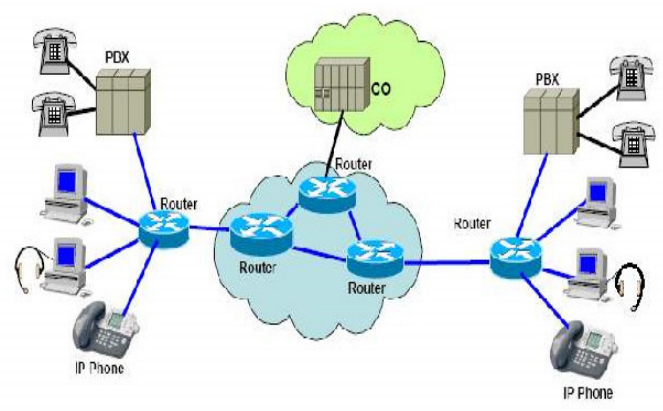

Gbr. 1 Penggabungan Jaringan PSTN dan VoIP

\section{Protokol Jaringan VoIP}

Berdasarkan fungsinya, protokol pada VoIP dapat dibedakan menjadi 2 yaitu protokol persinyalan dan media transfer. Protokol persinyalan digunakan untuk membangun, menjaga suatu sesi komunikasi yang sedang berlangsung, dan memutus suatu koneksi. Sedangkan protokol media transfer berfungsi untuk mengatur komunikasi pada saat transfer data (baik voice, video, maupun data) secara realtime berlangsung dengan baik.

Saat ini terdapat banyak sekali protokol signalling seperti H.323, SIP, SCCP, MGCP, MEGACO, dan SIGTRAN. Tetapi yang paling populer dan banyak digunakan adalah H.323, dan SIP. Dimana Protokol H.323 dikembangkan oleh ITU-T sedangkan SIP dikembangkan oleh Internet Engineering Task Force (IETF). Dalam tugas akhir ini hanya protokol SIP saja yang akan dijelaskan.

- Signalling Protocol - Session Initiation Protocol (SIP)

SIP merupakan sebuah protokol yang bekerja pada layer aplikasi, yang berfungsi untuk membentuk, memodifikasi, dan mengakhiri sesi komunikasi antara satu atau lebih endpoint. Yang terkandung dalam sesi antara lain data-data konfrensi multimedia. Sesi multimedia adalah pertukaran data antar pengguna yang bisa meliputi suara, video, dan text. SIP merupakan protokol berbasis teks, yang menyerupai HTTP dan SMTP, karena SIP merupakan protokol signaling dan bukan media transfer protokol. Maksud dari protokol signaling adalah SIP hanya menangani 
bagaimana satu client bisa terhubung dengan client lainnya, memberikan tanda seperti apakah koneksi berhasil atau tidak, apakah client mau menerima request dari client lain, apakah ada masalah koneksi yang terjadi, dan informasi lainnya. SIP tidak membawa paket data suara dan video. Jadi saat koneksi telah terjadi, masalah transfer data suara dan video bukan lagi dikerjakan oleh protokol SIP. SIP memanfaatkan RTP (Real Time Protocol) sebagai media transfer. Dua komponen utama SIP yaitu user agent dan network server.

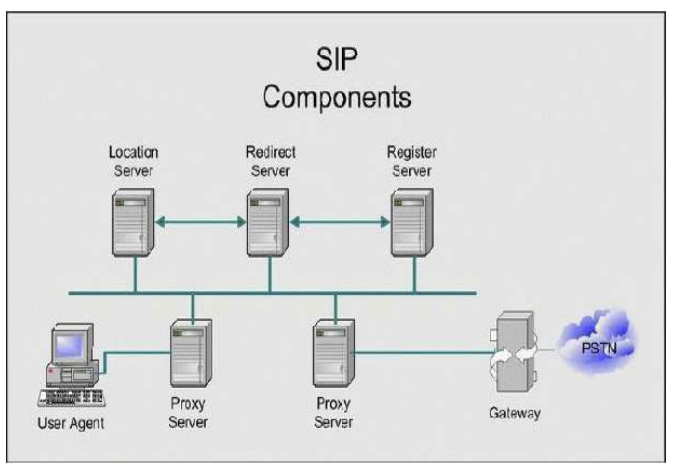

Gbr. 2 Arsitektur SIP

\section{- Protokol Media Transfer}

Protokol-protokol lain yang ikut berperan dalam proses transfer data suara pada jaringan VoIP diantaranya adalah protokol TCP/IP (Transfer Control Protocol/Internet Protocol), karena protokol ini merupakan protokol yang digunakan pada jaringan Internet. Protokol ini terdiri dari dua bagian besar, yaitu TCP dan IP. Selain itu terdapat juga protokol UDP (User Datagram Protocol).

\section{Kompresi Suara}

Pada prinsipnya pengodean suara merupakan pengalihan kode analog menjadi kode digital agar suara dapat dikirim dalam jaringan komputer. Pengodean ini dikenal dengan istilah codec (compressor-decompressor). Berbagai jenis dikembangkan untuk mengompresikan suara agar dapat menggunakan bandwidth secara hemat tanpa mengorbankan kualitas suara (didengar relatif baik).. Konversi codec bekerja dengan cara memotong bagian sinyal (sampling) audio dalam jumlah tertentu perdetiknya. Sebagai contoh, codec G.711 melakukan sampling audio sebanyak 64.000 kali per detiknya. Jika data hasil kompresi berhasil diterima di titik lain, proses selanjutnya adalah melakukan perakitan ulang. Data yang dirakit tidak selengkap data saat pertama kali dikirim, ada beberapa bagian yang hilang. Akan tetapi bagian yang hilang sangat kecil sehingga tidak terdeteksi oleh telinga manusia. Codec juga bekerja menggunakan alogaritma tertentu untuk membantunya memecah, mengurutkan, mngkompresi, dan merakit ulang audio data yang ditransmisikan. Salah satu alogaritma yang populer digunakan dalam teknologi VoIP adalah CS-ACELP (Conjugate-Structure AlgebraicCode-Excited Linear Prediction).

Pemilihan codec sangat berpengaruh pada penggunaan bandwidth jaringan nantinya. Makin baik codec melakukan sampling, makin efisien juga jalur yang digunakan. Kualitas akhir suara juga harus diperhatikan agar tidak sekadar cepat, codec juga harus menghasilkan sinyal audio yang baik. ITU-T (International Telecommunication Union - Telecommunication Sector) membuat beberapa standar untuk voice coding yang direkomendasikan untuk implementasi VoIP. Beberapa standar yang sering dikenal antara lain: G.711, G.723.1, G.726, G.728, G.729, GSM, iLBC

\begin{tabular}{|c|c|c|}
\hline Kompresi Suara & Laju Bit Rata-Rata (kbps) & Lisensi \\
\hline G.711 (PCM) & 64 & Tidak Ada \\
\hline G.726 & 32 & Tidak Ada \\
\hline G.723.1 & 5.3 dan 6.3 & Ada \\
\hline G.729A & 8 & Ada \\
\hline GSM & 13 & Tidak Ada \\
\hline ILBC & 15.2 & Tidak Ada \\
\hline
\end{tabular}

Gbr. 3 Perbandingan Jenis CODEC

\section{Parameter yang mempengaruhi QoS VoIP}

Quality of Service (QoS) adalah kemampuan suatu jaringan untuk menyediakan layanan yang lebih baik pada trafik data tertentu pada berbagai jenis platform teknologi. QoS tidak diperoleh langsung dari infrastruktur yang ada, melainkan diperoleh langsung dengan mengimplementasikannya pada jaringan bersangkutan. Penanganan QoS dilakukan dengan memanfaatkan sumber daya jaringan secara optimal, dibandingkan dengan menambah kapasitas fisik jaringan tersebut. Meningkatnya berbagai layanan akan meningkatkan lalu lintas aliran paket dengan berbagai laju kecepatan, yang akan membutuhkan kemampuan jaringan melalukan aliran paket pada laju kecepatan tertentu.Secara umum, ada beberapa parameterparameter penting yang mempengaruhi Quality of Service (QOS) layanan suara pada jaringan VoIP. Parameter ini dijadikan gambaran ukuran kinerja dari suatu jaringan VoIP. Beberapa parameter tersebut yaitu : 
- Delay

Dalam perancangan jaringan VoIP, waktu tunda merupakan suatu permasalahan yang harus diperhitungkan karena kualitas suara bagus tidaknya tergantung dari waktu tunda. Besarnya waktu tunda maksimum yang direkomendasikan oleh ITUT G.114 untuk aplikasi suara adalah 150 ms, sedangkan waktu tunda maksimum dengan kualitas suara yang masih dapat diterima pengguna adalah $250 \mathrm{~ms}$.

- Jitter

Jitter merupakan perbedaan selang waktu kedatangan antar paket di terminal tujuan. Jitter dapat disebabkan oleh terjadinya kongesti, kurangnya kapasitas jaringan, variasi ukuran paket, serta ketidakurutan paket. Faktor ini perlu diperhitungkan karena karakteristik komunikasi voice adalah sensitif terhadap waktu tunda dan jitter. Untuk meminimalisasi jitter dalam jaringan maka perlu diimplementasikan suatu buffer yang akan menahan beberapa urutan paket sepanjang waktu tertentu hingga paket terakhir datang. Buffer tersebut biasanya dikenal dengan istilah dejitter buffer. Namun hadirnya buffer tersebut akan mempengaruhi waktu tunda total sistem akibat adanya tambahan proses untuk mengompensasi jitter. Jitter berkategori baik jika $0-20 \mathrm{~ms}$ dan masih dalam batas toleransi apabila bernilai $20-50 \mathrm{~ms}$

- Packet loss

Sinyal suara pada telepon internet akan ditransmisikan dalam jaringan IP dalam bentuk paket-paket IP. Karena jaringan IP merupakan best-effort network maka tidak ada jaminan pada pengiriman paket tersebut. Setiap paket dapat dirutekan melalui jalur yang berbeda menuju penerima. Pada best-effort network tidak ada perbedaan antara paket voice dengan paket-paket data lainnya yang mengalir di jaringan. Maka dari itu tentunya ada kemungkinan terjadinya hilang paket pada saat transmisi. Tingkat paket hilang ini tentunya akan mempengaruhi kualitas layanan. Pada packet loss berkualitas baik apabila $0-1 \%$, dan tidak dapat di terima apabila $>10 \%$ dalam aplikasi suara.

\section{- $\quad$ Bandwidth}

Bandwidth adalah kapasitas atau daya tampung kabel ethernet agar dapat dilewati trafik paket data dalam jumlah tertentu. Bandwidth juga bisa berarti jumlah konsumsi paket data per satuan waktu dinyatakan dengan satuan bit per second (bps). Dalam perancangan VoIP, bandwitdh merupakan suatu yang harus diperhitungkan agar dapat memenuhi kebutuhan pelanggan yang dapat digunakan menjadi parameter untuk menghitung jumlah peralatan yang dibutuhkan dalam suatu jaringan. Perhitungan ini juga sangat diperlukan dalam efisiensi jaringan dan biaya serta sebagai acuan pemenuhan kebutuhan untuk pengembangan di masa mendatang.

Satuan ini menggambarkan seberapa banyak bit yang dapat melalui rute jaringan dari suatu tempat ke tempat lain setiap detiknya. Paket hilang dan desequencing merupakan masalah yang berhubungan dengan kebutuhan bandwidth, namun lebih dipengaruhi oleh stabilitas rute yang dilewati data pada jaringan, metode antrian yang efisien, pengaturan pada router, dan penggunaan kontrol terhadap kongesti (kemacetan paket data) pada jaringan. Besar bandwidth yang diperlukan untuk mentransmisikan suara melalui jaringan IP tergantung pada beberapa faktor, diantaranya adalah jenis kompresi suara yang digunakan, overhead dari paket VoIP, media transmisi, dan durasi paket VoIP yang ditransmisikan. Overhead mengacu pada kombinasi informasi IP, User Datagram Protocol (UDP), dan Real-Time Transport Protocol (RTP) di dalam format paket VoIP. Dalam konfigurasi yang paling umum, berikut adalah gambar yang menunjukkan format paket pada VoIP.

\section{Monitoring Jaringan Kampus Universitas Sam Ratulangi Manado}

Pada dasarnya penelitian ini dilakukan untuk mengetahui layak tidaknya implementasi VoIP di jaringan kampus Unsrat, oleh karena itu, sebelum menguji secara teknis terlebih dahulu dilakukan pemantauan jaringan di semua gedung yang telah terintegrasi jaringan internet untuk mengetahui pemakaian bandwidth (kondisi jaringan) yang ada di kampus Unsrat. Monitoring jaringan ini dilakukan dari awal hingga akhir semester genap.

Pada umumnya di awal perkuliahan semester genap aktifitas mahasiswa maupun dosen dalam hal belajar mengajar sudah mulai berjalan, sehingga tidak bisa dipungkiri untuk kebutuhan perkuliahan, akses internet begitu diperlukan. Pada pertengahan semester terjadi peningkatan pemakaian internet hal ini dikarenakan masa perkuliahan telah berjalan aktif disemua fakultas. Besarnya pemakaian bandwidth terletak di Pusat Teknologi Informasi (PTI) Unsrat dimana beban maksimum mencapai 4.09 Mbps, yang diikuti Fakultas Teknik 3.53 Mbps, dan gedung kantor pusat dengan 2.68 Mbps. Ketiga lokasi ini yang memiliki penggunaan bandwidth terbanyak diantara lokasi lainnya. Sedangkan diakhir semester UAS mulai berjalan sehingga kegiatan mahasiswa maupun dosen dalam hal belajar mengajar tidak seperti saat masa aktif kuliah, hal ini berimbas pada penggunaan akses internet yang terjadi disaat itu. 


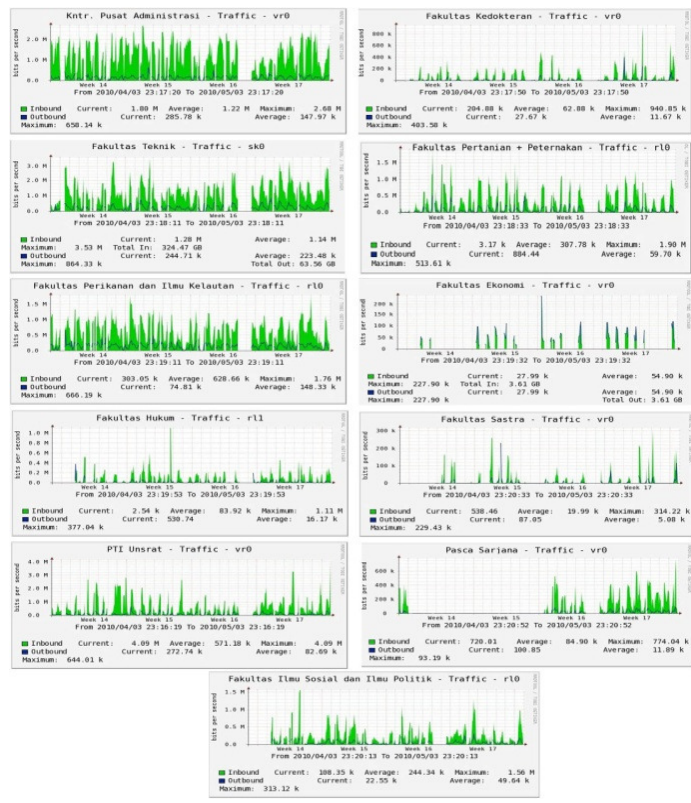

Gbr. 4 Peningkatan Penggunaan Internet pada Periode Pertengahan Semester

\section{Pengujian Kualitas Suara}

Pada sub bab ini berisi data-data yang di dapat selama pengujian dilakukan. Pengujian kualitas suara ini dilakukan pada beberapa keadaan jaringan. Analisis kualitas suara menggunakan berbagai codec, codec yang digunakan yaitu G.711, iLBC, dan GSM, mengingat ketiga codec ini tidak memiliki lisensi dan telah terintegrasi di berbagai softphone. Untuk menganalisa kualitas layanan VoIP digunakan software VQManager dimana dapat menampilkan beberapa parameter QoS (Quality of Service) seperti nilai waktu tunda, jitter, dan paket hilang pada suatu jaringan. Sedangkan untuk nilai MOS dan R-Faktor menngunakan metode E-Model. Diharapkan dari hasil pengukuran dan analis dengan menngunakan metode ini dapat ditentukan jenis codec yang baik untuk di implementasikan pada jaringan yang ada saat ini.

\section{- Pengujian Panggilan VoIP di Jaringan \\ Kampus}

Pengujian panggilan yang dilakukan bertempat di PTI dan Fakultas Teknik yang diujikan disetiap media koneksi baik LAN maupun WLAN. Kedua lokasi ini dipilih berdasarkan data hasil monitoring jaringan yang dilakukan, dimana kedua lokasi ini memiliki konsumsi bandwidth yang lebih besar dibanding lokasi lain di lingkungan kampus Unsrat. Prosedur pengujiannya yaitu, akan diuji kualitas suara di kedua lokasi ini, selanjutnya dilakukan panggilan dari PTI ke fakultas Teknik dengan menggunakan media koneksi yang telah ditentukan.
PTI

Tabel 1. Hasil Monitoring pada Jaringan PTI untuk Codec G.711, iLBC dan GSM

\begin{tabular}{lllll}
\hline \multicolumn{5}{c}{ PTI } \\
Media & Codec & Delay & Jitter & $\begin{array}{l}\text { Packet } \\
\text { Loss }\end{array}$ \\
LAN & G.711 & 1 & 2 & 0 \\
& iLBC & 1 & 2 & 0 \\
& GSM & 2 & 2 & 9 \\
Wireless & G.711 & 2 & 3 & 0 \\
& iLBC & 2 & 4 & 0 \\
& GSM & 6 & 12 & 0 \\
\hline
\end{tabular}

Fakultas Teknik

Tabel 2. Hasil Monitoring pada Jaringan Fakultas Teknik untuk Codec G.711, iLBC dan GSM

\begin{tabular}{lllll}
\hline \multicolumn{5}{c}{ Fakultas Teknik } \\
$\begin{array}{l}\text { Media } \\
\text { Koneksi }\end{array}$ & Codec & Delay & Jitter & $\begin{array}{l}\text { Packet } \\
\text { Loss }\end{array}$ \\
LAN & G.711 & 0 & 4 & 0 \\
& iLBC & 1 & 2 & 0 \\
& GSM & 2 & 1 & 9 \\
Wireless & G.711 & 2 & 10 & 0 \\
& iLBC & 2 & 12 & 0 \\
& GSM & 5 & 14 & 0 \\
\hline
\end{tabular}

Dalam teknologi VoIP, parameter delay disebabkan oleh beberapa komponen delay yang secara garis besar yaitu delay serialisasi, delay jitter buffer dan delay paketisasi. Pada pengujian di jaringan PTI dan Teknik, dengan media koneksi LAN maupun Wireless diperoleh nilai delay yang dihasilkan masih dalam rentang delay yang baik dalam transmisi untuk aplkasi suara yaitu berada pada nilai $0-150$ ms. Nilai delay berdasarkan data diatas disebabkan oleh delay serialisasi dimana nilainya akan semakin besar apabila menurunnya kapasitas jaringan karena delay serialisasi berbanding terbalik dengan kapasitas jaringan. Semakin kecil kapasitas jaringan maka semakin besar delay dan begitu juga sebaliknya semakin besar kapasitas maka delay serialisasi yang terjadi akan semakin kecil. Disamping itu, delay untuk skema kompresi (delay paketisasi) pada setiap codec ikut mempengaruhi kualitas suara dan jumlah bandwidth yang ditransmisikan. Codec dengan skema kompresi dan bit rate yang kecil akan membutuhkan sumber daya pemrosesan yang lebih besar karena besar bit rate berbanding terbalik dengan delay yang dihasilkan. Sebagai contoh, codec GSM dengan laju bit rate 13 kbps/20ms akan menghabiskan daya pemrosesan yang lebih besar dari codec G.711 $64 k b p s / 20 m s$. Hal ini tentu saja akan menambah delay paketisasi tetapi disisi lain akan menghemat 
kapasitas jaringan namun akan berdampak pula pada kualitas suara yang dihasilkan.

Untuk nilai jitter dari hasil monitoring yang dilakukan memiliki nilai yang bervariasi disetiap media koneksi namun masih tergolong baik untuk semua jenis codec karena tidak melebihi 20ms sesuai rekomendasi ITU. Nilai jitter ini terjadi akibat variasi beban trafik dan besarnya kemacetan antara paket (collision) yang terjadi pada jaringan IP. Semakin besar beban trafik di dalam jaringan maka akan semakin besar pula peluang terjadinya kongesti, selain itu pengaruh dari bitrate yang rendah membuat daya pemrosesan serta paketisasi yang meningkat pada jaringan yang memungkinan nilai dari jitter akan lebih besar. Hal ini sesuai hasil eksperimen yang diperoleh yaitu nilai jitter semakin meningkat pada jenis codec yang mempunyai bitrate yang kecil.

Secara teori, paket yang menggunakan RTP sebagai protokol transportnya memiliki kemungkinan paket karena karakteristik dari protokol RTP yang tidak menjamin pengiriman paket-paket data untuk sampai pada tujuan. Hal ini disebut dengan best effort delivery service. Pada saat transmisi, tidak ada perbedaan antara paket voice dengan paket-paket data lainnya yang mengalir di jaringan. Maka dari itu tentunya ada kemungkinan terjadinya hilang paket pada saat transmisi, dan paket hilang ini tentunya akan mempengaruhi kualitas layanan. Berdasarkan rekomendasi ITU bahwa nilai packet loss yang baik bernilai $0-1 \%$. Dari hasil pengukuran terlihat nlai packet loss dalam kategori baik yaitu bernilai nol. Pengaruh delay, Jitter dan packet loss yang diperoleh pada pengujian ini di sebebkan oleh beberapa faktor seperti halnya yang telah dijelaskan pada pengujian sebelumnnya karena topologi pengujian yang dilakukan cenderung sama.

\section{PTI - Fakultas Teknik}

Tabel 3. Hasil Monitoring pada Jaringan PTI - Fakultas Teknik untuk Codec G.711, iLBC dan GSM

\begin{tabular}{lllll}
\hline \multicolumn{5}{c}{ Fakultas Teknik } \\
\hline $\begin{array}{l}\text { Media } \\
\text { Koneksi }\end{array}$ & Codec & Delay & Jitter & $\begin{array}{l}\text { Packet } \\
\text { Loss }\end{array}$ \\
LAN & G.711 & 0 & 4 & 0 \\
& iLBC & 1 & 2 & 0 \\
& GSM & 2 & 1 & 9 \\
Wireless & G.711 & 2 & 10 & 0 \\
& iLBC & 2 & 12 & 0 \\
& GSM & 5 & 14 & 0 \\
\hline
\end{tabular}

Berdasarkan data yang diperoleh dari pengujian yang dilakukan dapat dilihat kenaikan nilai QoS yang cukup signifikan terjadi pada saat pengujian dilakukan pada media koneksi wireless. Hal ini terjadi karena sifat jaringan itu sendiri, kita ketahui bersama bahwa jaringan Wireless mempunyai sifat yang lebih rentan terhadap gangguan. Faktor multipath fading, pantulan, dan fasa yang berubah setiap saat juga sangat berpengaruh pada keutuhan paket yang diterima. Selain itu keadaan jaringan baik PTI maupun Fakultas Teknik berbeda setiap saat.

Adanya kenaikan nilai QoS ini tidak begitu berpengaruh untuk komunikasi yang dilakukan karena suara yang dihasilkan masih dapat diterima. Pernyataan ini dapat dibuktikan dengan data yang diperoleh dimana nilai delay dari kedua media koneksi yang diujikan tergolong baik. Sedangkan untuk jitter yang terjadi dapat dilihat nilai tertinggi diperoleh codec GSM untuk media wireless namun angka ini masih dapat diterima karena < 50ms. Packet loss terjadi disaat pengujian pada media wireless diujikan namun nilainya masih dapat diterima untuk standar komunikasi VoIP yaitu $<5 \%$.

Berdasarkan analisa yang dilakukan disetiap jaringan, kenaikan delay, jitter, dan packet loss, terjadi pada media koneksi wireless. Namun kita ketahui bersama wireless merupakan backbone pada jaringan Unsrat, dan yang menjadi jalur utama yaitu jaringan LAN yang telah terintegrasi dengan baik keseluruh segmen jaringan yang ada di Unsrat, sehingga hasil dari pengujian menunnjukkan tingkat kemerosotan jaringan yang diakibatkan gannguan lebih kecil dibanding media wireless

\section{Perhitungan Kualitas VoIP dengan E- Model}

Pada penelitian ini, akan dihitung nilai faktor R untuk codec G.711, iLBC, dan GSM.

Parameter-parameter yang digunakan sesuai data hasil monitoring panggilan VoIP di jaringan kampus. Berdasarkan rumus yang telah diketahui sebelumnya yaitu : $\mathrm{R}=93,2$ - Id - Ie, dimana nilai $\mathrm{R}$ kemudian dikorelasikan ke MOS dimana persamaan yang dipakai disesuaikan dengan hasil $\mathrm{R}$ yang didapat. Pada penelitian ini umumnya rumus korelasi yang digunakan yaitu: Untuk $0<$ $\mathrm{R}<100: \mathrm{MOS}=1+0.035 \mathrm{R}+7 \times 10-6 \mathrm{R}(\mathrm{R}-$ 60)(100-R). Tabel berikut merupakan hasil perhitungan yang dilakukan.

Dari Gbr. 5 dapat dilihat bahwa hasil MOS yang diperoleh dari pengujian secara keseluruhan berada pada kisaran 3,692 - 4,41 dimana codec G.711 memiliki tingkat kepuasan yang sangat baik walaupun bandwidth yang dibutuhkan cukup besar namun hal itu sebanding dengan kualitas suara yang dihasilkan. Sedangkan 
untuk codec iLBC memiliki tingkat kepuasan yang baik satu tingkat dibawah codec G.711, dan codec GSM dengan tingkat kepuasan yang cukup baik namun dalam melakukan komunikasi GSM hanya memerlukan bandwidth yang lebih kecil di banding dua jenis codec sebelumnya. Dari hasil perhitungan ini kiranya dapat dilihat jenis codec yang nantinya layak digunakan apabila teknologi ini diimplementasikan.

\begin{tabular}{|c|c|c|c|c|c|}
\hline Lokasi & $\begin{array}{c}\text { Media } \\
\text { Koneksi }\end{array}$ & codec & Faktor R & MOS & $\begin{array}{c}\text { Tingkat } \\
\text { Kepuasan }\end{array}$ \\
\hline \multirow{6}{*}{ PTI } & \multirow{3}{*}{ LAN } & G.711 & 93.176 & 4.4088 & Sangat Baik \\
\hline & & iLBC & 82.176 & 4.1035 & Baik \\
\hline & & GSM & 73.152 & 3.74 & Cukup Baik \\
\hline & \multirow{3}{*}{ WLAN } & G.711 & 93.152 & 4.4083 & Sangat Baik \\
\hline & & iLBC & 82.152 & 4.1023 & Baik \\
\hline & & GSM & 73.036 & 3.736 & Cukup Baik \\
\hline \multirow{6}{*}{ Teknik } & \multirow{3}{*}{ LAN } & G.711 & 93.2 & 4.41 & Sangat Baik \\
\hline & & iLBC & 82.176 & 4.1035 & Baik \\
\hline & & GSM & 73.152 & 3.74 & Cukup Baik \\
\hline & \multirow{3}{*}{ WLAN } & G.711 & 93.152 & 4.4083 & Sangat Baik \\
\hline & & iLBC & 82.152 & 4.1023 & Baik \\
\hline & & GSM & 73.08 & 3.378 & Cukup Baik \\
\hline \multirow{6}{*}{ PTI-Teknik } & \multirow{3}{*}{ LAN } & G.711 & 93.176 & 4.4088 & Sangat Baik \\
\hline & & iLBC & 82.152 & 4.1023 & Baik \\
\hline & & GSM & 73.152 & 3.74 & Cukup Baik \\
\hline & \multirow{3}{*}{ WLAN } & G.711 & 92.528 & 4.396 & Sangat Baik \\
\hline & & iLBC & 81.384 & 4.075 & Baik \\
\hline & & GSM & 72.072 & 3.692 & Cukup Baik \\
\hline
\end{tabular}

Gbr. 5 Hasil Perhitungan Nilai MOS dari Korelasi Faktor R

\section{Kesimpulan}

1) Kualitas suara yang dihasilkan teknologi VoIP bergantung kepada jenis codec yang digunakan, bandwidth, delay, jitter, packet loss serta kualitas jaringan.

2) Aplikasi VoIP layak diimplementasikan di jaringan kampus Unsrat hal ini dapat dilihat dari nilai delay, jitter, packet loss yang termasuk dalam kategori baik untuk aplikasi suara selain itu nilai MOS yang didapat dari pengujian secara keseluruhan yaitu berada pada kisaran 3,69 - 4,41 yang mengindikasikan kualitas suara yang diujikan pada jaringan tergolong baik.

3) Dari pengujian codec yang digunakan diperoleh codec G711 memiliki tingkat kepuasan yang sangat baik dilihat dari Nilai MOS nya, sehingga jenis codec ini bisa menjadi alternatif untuk komunikasi VoIP di jaringan kampus Unsrat.

4) Universitas Sam Ratulangi telah memiliki infrastruktur jaringan yang memungkinkan penerapan teknologi VoIP.

\section{Referensi}

[1] Sugeng, Winarno. 2008. "Membangun Telepon berbasis VoIP”. Penerbit Informatika. Bandung

[2] Purbo, Onno.W, 2007. "VoIP Cikal Bakal Telkom Rakyat”, PT Prima Infosarana Media, Jakarta.

[3] Raharja, A. 2006. Jaringan VoIP Berbasiskan Protokol SIP. VoIP Rakyat: Jakarta.

[4] Utomo, Eko. 2007 "Pengantar jaringan komputer". Yrama Windya

[5] Meggelen, J.V. Madsen, L., and Smith, J. 2007. The Future of Telephony, Second Edition. O'Reilly Media: CA, USA

[6] Tharom, T. 2002. "Teknis dan Bisnis VoIP”. Jakarta: PT. Media Elex Komputindo.

[7] Juanda, Enjang, dkk. 2008. “Analisis Traffic Bandwidth Layanan Internet di Direktorat TIK UPI. Bandung, Indonesia: Universitas Pendidikan Indonesia

[8] Grandistyana, A. dan Sudarmawan. "Kajian Kerja Protokol Pada Jaringan VoIP pada Jaringan Internet UGM”. Yogyakarta: STMIK AMIKOM.

[9] ITU-T G.107 .2005. "The E-model, a Computational Model For Use in Transmission Planning". ITU-T Recommendation G.107.

[10] Recommendation G.113 Amendment 1 (03/09). 2009. "Provisional planning values for the wideband equipment impairment factor and the wideband packet loss robustness factor". 